Doi: https://doi.org/10.24036/jep/vol5-iss2/592

\title{
Analisis Kebutuhan Penilaian Capaian Literasi STEM Peserta Didik dalam Pembelajaran Biologi
}

\author{
Maisyarah Ayu Budi Ningrum ${ }^{1)}$, Yosi Laila Rahmi ${ }^{2)}$ \\ ${ }^{1)}$ Program Studi Pendidikan Biologi, FMIPA, Universita Negeri Padang \\ ${ }^{2)}$ Jurusan Biologi, FMIPA, Universitas Negeri Padang \\ maisyarahayu42@gmail.com
}

\begin{abstract}
STEM literacy in education aims to prepare students compete in the world of education, the world of work, and the future. The benefit of STEM Literacy is that it makes students more skilled in all areas including science, technology, mathematics, and engineering. In addition, STEM literacy can also make students improve their critical thinking skills and become creative, logical, innovative, productive and relate directly to real conditions. This study aims to analyze the needs of students' STEM literacy achievement assessment in learning biology. The type of research used is descriptive, with data collection techniques carried out by conducting observations and interviews. The results showed that biology learning has been implemented based on STEM literacy, students are still less enthusiastic in reading, students are more interested in learning related to technology, teachers do not know the assessment of students' STEM literacy achievement in biology learning.
\end{abstract}

Keywords : STEM literacy, Achievement of STEM literacy, Biology

\section{PENDAHULUAN}

Perkembangan teknologi terus meng alami kemajuan seiring dengan perkembang an zaman. Perkembangan teknologi di era globalisasi ini sangat mempengaruhi sistem pendidikan di dunia. Hal tersebut juga memberi dampak terhadap pendidikan di Indonesia. Salah satu dampaknya yaitu terciptanya inovasi-inovasi baru yang dapat mendorong terlaksananya pembelajaran di sekolah, seperti media pembelajaran yang menggunakan animasi, video pembelajaran, game edukasi dan lain-lain.

Pada tahun 2020 sistem pendidikan di Indonesia mengalami perubahan. Hal terse but dikarenakan dampak dari pandemi COVID-19. Dampak tersebut memaksa seko lah-sekolah melakukan kegiatan pembela jaran dilakukan secara online atau daring di rumah peserta didik masing-masing, seperti penggunaan platform belajar edmodo, scho logy, dan lain-lain. Hal tersebut sejalan dengan pendapat Hidayat (2020) dampak dari COVID-19 membuat proses pembelajaran di sekolah dialihkan ke rumah peserta didik masing-masing melalui pembelajaran daring, sehingga perkembangan teknologi yang cepat menjadi faktor penting dalam menyelesaikan masalah pendidikan saat pandemi COVID-19 saat ini.

Jika dilihat kondisi pendidikan di Indonesia saat ini, masih belum mampu mengikuti laju perkembangan teknologi. Sehingga pembelajaran menggunakan tekno logi seperti daring masih belum bisa dilaksanakan scara maksimal. Hal ini sejalan dengan pendapat Sari (2012) bahwa kondisi tersebut disebabkan oleh rendahnya opera sional guru terhadap teknologi dan banyak sekolah di Indonesia belum mampu meme nuhi ketersediaan sarana dan prasarana untuk menunjangan teknologi informasi di sekolah, semisal jaringan internet dan ruang komputer bagi peserta didik. Selain itu juga dipenga ruhi oleh kualitas sumber daya manusia (SDM) dan ketersediaan finansial yang belum memadai.

Kualitas sumber daya manusia dan kualitas pemdidikan di negara Indonesia dapat dilihat dari capaian literasi sains peserta didik. Programme for International 
Student Assessment (PISA) merupakan sistem ujian yang diinisasi oleh Organisation for Economic Cooperation and Development (OECD), untuk mengevaluasi sistem pendi dikan di 77 negara di dunia.

Sejalan dengan hasil survei yang dari PISA, berdasarkan survei tersebut yang diselenggarakan oleh Trends in Inter national Mathematics and Science Study (TIMSS) yang merupakan studi penilaian internasional untuk pengetahuan matema tika dan sains peserta didik yang dilakukan setiap empat tahun sekali pada tahun 2007 Indonesia berada di peringkat ke 36 dari 49 negara dan tahun 2011 Indonesia berada di peringkat 39 dari 42 negara (NCES, 2012). Hasil tersebut menunjukkan bahwa skor rata-rata literasi sains peserta didik Indo nesia berada di bawah rata-rata skor internasional, yaitu dengan skor 397.

Rendahnya literasi STEM perseta didik disebabkan karena peserta didik di Indonesia tidak terbiasa dalam mengerjakan soal-soal yang berbasis berpikir tingkat tinggi (HOTS) dan guru-guru di Indonesia jarang menggunakan perangkat evaluasi yang berbasis literasi STEM (Fraenkel, dkk. 2012).

Rendahnya literasi sains peserta didik di Indonesia menjadikan hal tersebut sebagai suatu masalah yang harus diselesaikan. Para mentri pendidikan, pendidik (guru atau dosen), dan calon guru untuk mencari solusia dalam menyelesaikan masalah tersebut. Literasi STEM merupakan salah satu solusi yang dapat di terapkan dalam pendidikan, untuk membantu menciptakan sumber daya manusia (SDM) yang dapat menguasi saintek. Hal ini sejalah dengan pendapat Rifandi dan Rahmi (2020) Pendidikan STEM sangat penting bagi peserta didik untuk kehidupan setelah lulus sekolah supaya dapat bersaing di era modern sekarang ini.

STEM adalah singkatan dari bidang ilmu Science, Technology, Engineering, dan Mathematics. Pendidikan STEM diperkenal kan pertama kali oleh National Science Foundation (NSF) di awal tahun 2000an dan hingga saat ini telah banyak proyek yang didanai oleh organisasi. Meskipun STEM diterapkan pada kebijakan, acara, atau kurikulum yang dihubungkan dengan sains, teknologi, teknik, dan matematika, terutama berfokus pada sains dan matematika, khusus nya dalam pendidikan K-12. Dengan mengin tegrasikan empat disiplin ilmu dalam satu paradigma kohesif, pendidikan STEM bertuju an mempersiapkan siswa untuk menjadi pemecah masalah yang kreatif dan inovatif, peneliti, insinyur, dan desainer (Khosrow dan Pour, 2015).

Pendidikan berbasis STEM banyak digunakan di Negara Amerika Serikat, karena pendidikan berbasis STEM sangat efektif digunakan untuk meningkatkkan kualitas dan kedisiplinan peserta didik di sekolah. Sekolah yang menerapkan STEM melakukan pendekatan dengan Science, Technology, Engineering, dan Mathematics, salah satu penerapannya dengan mengeksplorasi peneli tian tentang kondisi sekolah, hal tersebut dapat mendukung terlaksananya Pendidikan STEM dengan efektif (Beatty dan Rappor teur, 2011).

Pembelajaran berbasis STEM sudah diterapkan di beberapa perguruan tinggi dan sekolah di Indonesia dari tahun 2013. Hal tersebut sesuai dengan pendapat Suwarma (2015) implementasi pendidikan STEM di Indonesia sudah mulai dilaksanakan bertepat an dengan kegiatan pelatihan guru, analisis konten kurikulum 2013 dan KTSP, serta kegiatan pelatihan berbasis STEM.

Pendidikan STEM menekankan pada pembelajaran yang berbasis pemecahan masalah dan berpikir kritis dengan mengait kannya dalam aspek sains, matematika, teknologi dan teknik, hal ini sejalan dengan pendapat Rifandi dan Rahmi (2019) pendidikan STEM adalah pembelajaran yang dapat mengaitkan dan menerapkan sains, teknologi, teknik dan matematika untuk meningkatkan keterampilan peserta didik dalam pemecahan masalah. Integrasi STEM adalah proses belajar mengajar materi praktik disiplin ilmu yang meliputi IPA atau matematika melalui integrasi praktik teknik dan desain rekayasa teknologi yang relevan.

Pendidikan STEM yang diterapkan disekolah kepada peserta didik memiliki banyak manfaat, hal ini sejalan dengan pendapat Winarni, Zubaidah, dan Koes (2016) STEM mempunyai manfaat ialah membuat peserta didik menjadi dapat meme cahkan masalah, bernalar berdasarkan hipo tesis, dan mampu menggabungkan sejumlah informasi dalam proses pembelajaran. 
Literasi STEM dalam pembelajaran biologi sangat berdampak positif. Hal ini didukung oleh penelitian Aninda (2019) dimana literasi STEM dapat membuat peserta didik menjadi lebih kreatif, dapat mendefinisi kan masalah, melakukan investigasi, menaf sirkan data, menggunakan teknologi infor masi, merancang solusi, terlibat argumen berdasarkan bukti, memperoleh, mengeva luasi dan mengkomunikasikan informasi.

Penerapan literasi STEM di sekolah sudah mulai di laksanakan di berbagai sekolah, sehingga penting untuk mengetahui penilaian capaian literasi STEM peserta didik. Penilaian capaian literasi STEM peserta didik perlu dilakukan untuk mengetahui tingkat kesuksesan metode atau model pembelajaran yang dilakukan sekolah untuk meningkatkan literasi STEM peserta didik. Salah satu bentuk partisipasi negara Indonesia dalam pendidikan di dunia adalah menjadi salah satu partisipan dalam penilaian literasi sain yang diselenggarakan oleh OECD. (Wahyuni, 2019).

Perlunya mengetahui penilaian capai an literasi STEM peserta didik supaya dapat melihat keberhasilan dan ketepatan pembe lajaran yang dibuat oleh guru. Selain itu juga dapat melihat pengaruh literasi STEM terhadap tingkat pemahaman peserta didik berdasarkan pemecahkan masalah, bernalar berdasarkan hipotesis, dan menggabungkan sejumlah informasi dalam proses pembe lajaran. Berdasarkan temuan yang diperoleh, peneliti ingin mengetahui kebutuhan peni laian capaian literasi STEM perserta didik dalam pembelajaran biologi. Oleh karena itu, tujuan dari penelitian ini adalah untuk dapat mengetahui kebutuhan penilaian capaian literasi STEM peserta didik dalam pembe lajaran biologi.

\section{METODE PENELITIAN}

Jenis penelitian yang dilakukan adalah penelitian deskriptif. penelitian deskriptif merupakan penelitian yang mencoba mendeskripsikan suatu keadaan, peristiwa, atau kejadian yang sedang berangsung atau yang sudah terjadi dan diungkapkan sebagai mana adanya tanpa manipulasi. Pada peneli tian ini peneliti berusaha membuat hasil penelitian berdasarkan fakta yang ada tanpa manipulasi data.
Penelitian deskriptif yang dilakukan yaitu mendeskripsikan kebutuhan penilaian capaian litarasi STEM peserta didik dalam pembelajaran biologi. Populasi pada peneli tian ini yaitu kepada 1 guru biologi dan 110 peserta didik kelas $\mathrm{X}$ di SMAS Cendana Mandau.

Teknik pengumpulan data yang dilakukan dalam penelitian ini melalui wawancara kepada guru biologi SMAS Cendana Mandau dan observasi ke SMAS Cendana Mandau. Angket wawancara yang digunakan berhubungan dengan literasi STEM, yang membahas pengetahuan tentang literasi STEM, manfaat literasi STEM, dan pembelajarn berbasis literasi STEM yang digunakan oleh guru. Pada penelitian ini peneliti mengobservasi ke sekolah SMAS Cendana Mandau, dengan melihat proses belajar di sekolah tersebut dan melakukan wawancarai kepada guru biologi dan peserta didik di SMAS Cendana Mandau untuk mengetahui perlunya mengetahui capaian literasi STEM peserta didik dalam pembe lajaran biologi.

Alat yang digunakan dalam mengukur suatu kejadian yang akan diteliti disebut instrument penelitian (Sugiyono, 2017). Instrumen yang digunakan berupa lembar wawancara. Instrumen penelitian telah melalui proses validasi oleh dosen biologi FMIPA UNP.

Teknik analisis data yang digunakan adalah analisis deskriptif kualitatif yang datanya diperoleh dari hasil observasi dan wawancara kepada guru SMAS Cendana Mandau. Proses analisis data yang dilakukan yaitu menganalisis kebutuhan penilaian capaian literasi STEM peserta didik dalam pembelajaran biologi.

\section{HASIL DAN PEMBAHASAN}

Analisis hasil wawancara peneliti dengan guru biologi SMAS Cendanan Mandau diperoleh data seperti yang tercantum pada Tabel 1 . 
Tabel 1. Hasil observasi dan wawancara di SMAS Cendana Mandau

\begin{tabular}{|c|c|}
\hline No. & Hasil observasi \\
\hline 1. & $\begin{array}{l}\text { Guru biologi di SMAS Cendana } \\
\text { Mandau sudah menerapkan } \\
\text { pembelajaran berbasis literasi } \\
\text { STEM. }\end{array}$ \\
\hline 2. & $\begin{array}{l}\text { Peserta didik masih kurang antusias } \\
\text { dalam membaca. }\end{array}$ \\
\hline 3. & $\begin{array}{l}\text { Peserta didik lebih tertarik dengan } \\
\text { pembelajaran yang berkaitan } \\
\text { dengan teknologi. }\end{array}$ \\
\hline 4. & $\begin{array}{l}\text { Peserta didik banyak yang belum } \\
\text { mengetahui literasi STEM }\end{array}$ \\
\hline 5. & $\begin{array}{l}\text { Guru belum mengetahui rumusan } \\
\text { evaluasi yang tepat untuk melihat } \\
\text { capaian literasi STEM peserta } \\
\text { didik. }\end{array}$ \\
\hline
\end{tabular}

Berdasarkan hasil observasi yang peneliti lakukan di SMAS Cendana Mandau pada tanggal 14 Juni 2021 didapatkan bahwa SMAS Cendana Mandau sudah menerapkan pembelajaran berbasis literasi STEM. Guru biologi di SMAS Cendana Mandau menerap kan literasi STEM dalam pemberajaran biologi dengan mengaitkannya dengan kehidupan sehari-hari peserta didik dan guruguru di SMAS Cendana Mandau membuat soal ujian yang berbasis literasi STEM.

Pembelajaran biologi berbasis literasi STEM yang diterapkan di sekolah kurang diminati oleh peserta didik, karena peserta didik kurang antusias dalam membaca hal tersebut sejalan dengan pendapat Harini (2018 : 16) bahwa peserta didik memiliki tingkat literasi rendah karena beberapa faktor, yaitu kurangnya intensitas membaca buku, tidak adanya sarana dan prasarana yang mendukung kebiasaan membaca seperti buku, komputer, perpustakaan yang nyaman, pendi dikan orang tua yang tidak mendukung kebiasaan membaca, dan anggapan peserta didik dalam membaca yang kurang baik.

Dalam proses pembelajaran peserta didik lebih tertarik pada pembelajaran yang berkaitan dengan teknologi seperti pembe lajaran yang dilakukan dengan video animasi dan pembelajaran menggunakan game edu kasi. Peserta didik di SMAS Cendana Mandau mengganggap pembelajaran dengan video animasi dan pembelajaran mengguna kan game edukasi lebih menarik dari pada hanya mendengarkan penjelasan dari guru atau hanya mencatat materi dari guru. Guru biologi di SMAS Cendana Mandau memodi fikasi metode pembelajaran yang menarik dengan menggabungkan video pembelajaran yang inovasi dan kreatif dengan mengait kannya dengan literasi STEM.

Penerapan Literasi STEM dalam pembe lajaran biologi membuat guru lebih tertan tang untuk dapat menerangkan materimateri yang berkaitan dengan STEM kepada peserta didik dan menjadikan guru kreatif dalam membuat soal-soal berbasis literasi STEM namun, guru belum mengetahui rumusan evaluasi yang tepat untuk penilaian capaian literasi STEM peserta didik dalam pembe lajaran biologi.

Literasi STEM sangatlah penting untuk diterapkan dalam pendidikan di Indonesia karena dapat menciptakan peserta didik yang berkualitas serta mampu bersaing di era globalisasi, sejalan dengan pendapat Rifandi dan Rahmi (2020: 1) STEM dapat mempersiapkan peserta didik dengan bebe rapa keterampilan termasuk kemampuan ber adaptasi dengan banyak situasi, kemampuan berkomunikasi pada tingkat yang lebih ting gi, kemampuan dalam pemecahan masalah, dan memiliki manajemen diri yang baik.

STEM education atau kita sebut pendidikan STEM merupakan kombinasi antara Science, Technology, Engineering, dan Mathematics. Pendidikan STEM sendiri betujuan untuk dapat mengembangkan kemampuan dan keterampilan pada peserta didik yaitu membuat peserta didik mampu untuk mengajukan pertanyaan atau berpikir kritis, (2) peserta didik mampu merencana kan dan melaksanakan penyelidikan, (3) peserta didik mampu merancang, mengem bangkan dan menggunakan model, (4) peserta didik mampu menggunakan mate matika dan menerapkan matematika dalam kehidupan dan peserta didik dapat berpikir komputasi, (5) peserta didik mampu meng analisis dan menafsirkan data, (6) peserta didik dapat membangun penjelasan (7) 
peserta didik dapat melakukan argumen dari bukti, (8) dan peserta didik mampu men dapatkan, mengevaluasi, dan mengkomuni kasikan informasi yang didapat.

Pendidikan STEM sudah mulai diterap kan di berbagai negara, baik negara maju maupun negara berkembang. Pendidikan STEM dinilai merupakan jalan keluar untuk meningkatkan kualitas sumber daya manusia di suatu negara (Subekti, dkk, 2018).

Literasi STEM terdiri dari 4 aspek yaitu: aspek literasi sains, dimana menerap kan pembelajaran dengan menggunakan pengetahuan ilmiah dan mengkaitkan pembe lajaran dengan alam disekitar. Aspek literasi teknologi, dimana mengkaitkan pembe lajaran dengan teknologi, seperti dapat menggunakan, menganalisis dan mengem bangkan teknologi. Aspek literasi teknik merupakan pemahaman terhadap teknologi yang dikembangkan melalui proses desain. Pemahaman tersebut ditandai dengan dapat menggunakan tema pembelajaran yang berbasis proyek dengan cara, dapat meng integrasikan beberapa mata pelajaran. Sedangkan aspek literasi matematika meru pakan kemampuan dalam merumuskan, menyelesaikan masalah dengan penilaian, mampu menafsirkan solusi masalah matema tika dalam penerapannya dan mampu meng komunikasikan ide scara efektif (Herak dan Lamanepa, 2019).

Pendidikan STEM memiliki tujuan utama pengembangan sains, teknologi, konsep teknik dan matematika, pengetahuan dan pemahaman proses, melalui upaya untuk menggabungkan beberapa atau semua dari empat disiplin ilmu menjadi satu unit. Dengan car aini, pendidikan STEM dapat menghubungkan antara masalah dunia nyata dengan subjek (Fallon, 2020).

Pendidikan STEM merupakan solusi untuk meningkatkan kualitas sumber daya manusia (SDM). Pendidikan STEM sendiri sudah banyak diterapkan di negara maju seperti Jepang, Korea, dan Australia serta di negara berkembangpun sudah banyak yang menerapkan pendidika STEM seperti Malay sia, Thailand, dan Philiphina (Wijayanti, 2018). Pentingnya pendidikan STEM sudah mulai disadari oleh pakar pendidikan di Indonesia, sehingga hampir di seluruh perguruan tinggi di Indonesia melakukan kajian pengembangan pendidikan STEM.

Perkembangan teknologi merupakan faktor utama dalam perubahan tuntutan dunia. Tututan dunia di abad 21 saat ini menjadikan kehidupan manusia berbasis pada teknologi. Dengan dasar ini, para pendidik harus dapat menyiapkan generasi muda yang mampu bersaing scara global, serta dapat menguasai perkembangan teknologi di zaman ini, karena hal tersebut merupakan hal yang penting untuk peserta didik dalam bersaing di dunia pekerjaan di zaman sekarang. Sumber daya manusia yang dicari sekarang adalah manusia dapat memanfaatkan teknologi dan menggunakan teknologi dengan baik. Pendi dikan yang berbasis literasi STEM dipercaya dapat menjadi solusi untuk dapat menghasil kan sumber daya manusia (SDM) yang berkualitas dan dapat bersain scara global.

Dalam menghadapi era persaingan global dengan perkembangan teknologi yang pesat, Indonesia perlu menyiapkan SDM yang handal dalam berbagai aspek-aspek pada STEM secara kualitas dan kuantitas. Surat kabar yang dirilis Kompas bulan Juli tahun 2015, menyebutkan bahwa Indonesia mengalami kendala antara peluang pekerjaan dengan tenaga kerja yang banyak. Berdasar kan hasil survei oleh American Community tahun 2014, tingkat lowongan pekerjaan untuk lulusan STEM sebanyak 30\%. Tingkat pengangguran dengan lulusan STEM lebih rendah daripada lulusan non-STEM. Hal ini disebabkan karena kota-kota besar lebih membutuhkan pekerja yang beraitan dengan STEM.

Pendidikan berbasis literasi STEM merupakan tantangan bagi seorang pendidik dalam mengaplikasikan pembelajaran yang dapat mengaitkan pengetahuan dan keteram pilan. Kesiapan guru dalam menerapkan pembelajaran biologi berbasis literasi STEM dikatakan berhasil dimana jika guru mampu membangun suasana kelas yang menyenang kan dan mampu membuat peserta didik berhasil untuk mencapai tujuan belajarnya. Sejalan dengan pendapat Muh Ilyas (2010) dalam Anugraheni (2017) keberhasilan guru dalam memainkan peran penting dalam proses pembelajaran di kelas adalah dapat membantu peserta didik untuk bisa membangun sikap yang positif, meningkat kan rasa ingin tahu peserta didik, menjadikan 
peserta didik yang mandiri dan ketepatan logika intelektual, serta peserta didik dapat menciptakan kondisi-kondisi untuk membuat nya sukses/fokus dalam belajar. Selain itu, keberhasilan guru dalam proses pembelajaran bisa juga dilihat dari hasil penilaian capaian peserta didik. Hasil wawancara guru biologi di SMAS Cendana Mandau belum menge tahui rumusan evaluasi yang tepat untuk melihat capaian literasi STEM peserta didik di sekolah. Akibatnya guru tidak mengetahui tingkat keberhasilan mereka dalam proses pembelajaran yang dilaksanakan.

Peserta didik yang memiliki literasi STEM yang tinggi akan mampu untuk berpikir kritis dan mampu menyelaikan masalah yang kompleks, baik dari menjawab soal ataupun mengerjakan tugas-tugas. Sedangkan peserta didik yang rendah cenderung tidak mampu berpikir kritis dan tidak mampu dalam menyelesaikan masalah maupun mengerjakan soal dengan baik.

Kebutuhan penilaian capaian literasi STEM peserta didik dalam pembelajaran biologi sangat diperlukan supaya mampu melihat ketepatan dan keberhasilan pembe lajaran yang dibuat selain itu juga dapat melihat pengaruh literasi STEM terhadap tingkat pemahaman peserta didik berdasarkan pemecahkan masalah, bernalar berdasarkan hipotesis, dan mampu menggabungkan sejum lah informasi dalam proses pembelajaran.

Penilaian capaian literasi STEM peserta didik perlu diketahui oleh guru supaya guru dapat mengetahui keberhasilan pembelajaran yang dilakukan dan dapat juga melihat pengaruh literasi STEM terhadap hasil berajar peserta didik dan keterampilan peserta didik dalam berpikir kritis, dapat memecahkan masalah serta dapat menjadikan peserta didik yang dapat bersaing di era globalisasi.

Analisis penilaian capaian literasi STEM peserta didik dalam pembelajaran biologi bisa dilakukan dengan melakukan tes. Guru dapat memberikan soal berbasis literasi STEM kepada peserta didik, soal dapat di ambil dari soal PISA atau dari kreativitas guru. Dari hasil tes tersebut bisa didapatkan hasil persentase capaian literasi STEM peserta didik, untuk mengetahi capaian literasi STEM peserta didik bisa menggunkan rumus berikut:

$$
P=\frac{f}{N} x 100 \%
$$

Keterangan:

$P=$ persentase

$f=$ frekuensi

$N=$ jumlah Sampel

Hasil capaian literasi STEM peserta didik dapat dilihat dari kriteria penilaian kemampuan literasi peserta didik mengguna kan kategori penilaian seperti yang tercantum pada Tabel 2 .

Tabel 2. Kriteria Penilaian Kemampuan Literasi STEM

\begin{tabular}{cc}
\hline Kategori & Interval \\
\hline Sangat Tingi & $86-100$ \\
Tinggi & $76-85$ \\
Sedang & $60-75$ \\
Rendah & $55-59$ \\
& \\
Sangat Rendah & $<54$
\end{tabular}

Purwanto (2008)

Kriteria penilaian kemampuan literasi STEM peserta didik dapat menjadi acuan guru untuk melihat tingkat keberhasilan metode yang digunakan. Jika capaian literasi STEM peserta didik termasuk kategori sangat rendah dan rendah maka metode guru mengajar harus diperbaiki, sedangkan jika capaian literasi STEM peserta didik berada di kategori sedang maka metode mengajar guru sudah berhasil tetapi perlu sedikit perbaikan dan guru perlu mencari tahu penyebab kurang maksimalnya metode yang dipakai. Sedang kan untuk capaian literasi STEM peserta didik yang termasuk kategori tinggi dan sangat tinggi maka metode yang guru gunakan sudah berhasil dan tujuan guru sudah bisa dicapai.

Berdasarkan hasil penelitian maka kebutuhan penilaian capaian literasi STEM 
peserta didik dalam pembelajar biologi sangat diperlukan karena dapat mengetahui keberhasilan pembelajaran yang dilakukan oleh guru di sekolah dan untuk mengetahui pengaruh literasi STEM terhadap peserta didik.

\section{KESIMPULAN}

Berdasarkan hasil pembahasan yang peneliti lakukan maka dapat diambil kesim pulan yaitu bahwa tuntutan perkembangan teknologi dan ilmu pengetahuan saat ini terjadi menyebabkan manusia menghadapai tantangan dari berbagai aspek kehidupan sehingga dituntut untuk memiliki kualitas sumber daya manusia (SDM) yang lebih baik. Oleh karena itu, diperlukan analisis kebutuh an penilaian capaian literasi STEM peserta didik dalam pembelajaran biologi. Tujuan dari penilaian tersebut supaya mampu melihat ketepatan dan keberhasilan pembe lajaran yang dibuat, selain itu juga dapat melihat pengaruh literasi STEM terhadap tingkat pemahaman peserta didik berdasarkan pemecahkan masalah, bernalar berdasarkan hipotesis, dan mampu menggabungkan sejum lah informasi dalam proses pembelajaran di sekolah.

Berdasarkan hasil wawancara yang peneliti lakukan didapatkan bahwa di SMAS Cendana Mandau sudah menerapkan pembe lajaran biologi berbasis literasi STEM, peserta didik masih kurang antusias dalam membaca, peserta didik lebih tertarik dengan pembelajaran yang berkaitan dengan tekno logi, dan guru belum mengetahui rumusan evaluasi yang tepat untuk mengetahui penilaian capaian literasi STEM peserta didik pada pembelajaran biologi.

Berdasarkan hasil observasi yang peneliti lakukan didapatkan bahwa di SMAS Cendana Mandau sudah menerapkan pembe lajaran literasi STEM dengan sangat baik, dimana sudah terdapatnya sarana dan prasarana yang mendukung segala proses pembelajaran berbasis literasi STEM dan guru biologi di SMAS Cendana Mandau melaksanakan pembelajaran literasi STEM dengan memodifikasi metode pembelajaran yang menarik dengan membuat video pembelajaran yang inovasi dan kreatif dengan mengaitkan dengan literasi STEM.

\section{DAFTAR PUSTAKA}

ACS. (2014). Census Bureau Reports Majority of STEM College Graduates Do Not Work in STEM Occupations. American Community.

Anugraheni, I. (2017). Analisa Faktor-Faktor Yang Mempengaruhi Proses Belajar Guru-Guru Sekolah Dasar. Jurnal Manajemen Pendidikan. 4 (2), 205-212.

Aninda, A., Permanasari, A dan Ardianto. (2019). Implementasi Pembelajaran Ber basis Proyek pada Materi Pencemaran Lingkungan untuk Meningkatkan Lite rasi STEM Siswa SMA. Journal of Science Education and Practice, 3 (2), 116.

Beatty, A., dan Rapporteur. (2011). Successful STEM Education: A Workshop Sum mary. Washington, D.C: The National Academies Press.

Fallon, G., Hatzigianni, M., Bower, M., Forbes, A., dan Stevenson, M. (2020). Under standing K-12 STEM Education: a Framework for Developing STEM Lite racy. Journal of Science Education and Technology.

Fraenkel, dkk. (2012). How to Design and Evaluate Research in Education (Eight Edition). New York: McGraw Hill

Harini, I.N. Tingkat Literasi Membaca Peserta Didik Kelas Iv di Sd Muhammadiyah Bantul Kota. Jurnal Pendidikan Dasar Islam, 10 (1), 30-45.

Herak, R., \& Lamanepa, G. H. 2019. Meningkatkan Inovasi Siswa dalam Pembelajaran IPA Melalui STEM. Jurnal Bio Educatio, 4(2): 11.

Hidayat, D., Rohaya, A., Fildzah., dan Ramadhan, H. 2020. Kemandirian Belajar Peserta Didik dalam Pembe lajaran Daring pada Masa Pandemi Covid-19. Jurnal Ilmu Pendidikan, 34 (2), 147-153.

Inovasi Pendidikan Tingkat Daya Saing. 2015(15 Juli). Kompas, p.12.

Khosrow, M dan Pour. 2015. STEM Education: Concepts, Methodologies, Tools, and Applications. USA: IGI Global. 
National Center for Education Statistics (NCES). 2012. Highlights From TIMSS 2011: Mathematics and Science Achievement of U.S. Fourthand Eighth-Grade Students in an International Context. Washington, DC: U.S. Department of Education.

OECD. 2019. Survey International Program for International Student Assessment (PISA).

Purwanto, N. 2009. Prinsip-Prinsip dan Teknik Evaluasi Pengajaran. Bandung: Remaja Rosdakarya.

Rifandi, R dan Rahmi, Y.L. 2019. STEM Education to Fulfil the 21st Century Demand: A Literature Review. Journal of Physics. 1317(1). 012208.

Rifandi, R., Rahmi, Y.L., Widya., Indrawati, E.S. 2020. Pre-service Teachers' Perception on Science, Technology, Engineering, and Mathematics (STEM) Education. Journal of Physics: Conference Series. 1554 (1), 1-7.

Sari, M. 2012. Usaha Mengatasi Problematika Pendidikan Sains di Sekolah dan di Perguruan Tinggi. Jurnal Al-Ta'lim, 1(1), 74-86.

Subekti, H., Taufiq, M., Susilo, H., Ibrohim dan Suwono, H. 2018. Mengembangkan Literasi Informasi Melalui Belajar Berbasis kehidupan Terintegrasi STEM untuk Meneyiapkan Calon Guru Sains Dalam Menghadapi Era Revolusi Industri 4.0: Revieu Literatur. Education and Human Development Journal, 3(1), 81-90.

Sugiyono. (2017). Metode Peneitian Kuantitatif, Kualitatif, dan $R \& D$. Bandung: Alfa beta.

Suwarma, I. (2015). "Balloon Powered Car" Sebagai Media Pembelajaran IPA berbasis STEM (Science, Technology, Enginee ring, and Mathematics). Bandung: Prosi ding Simposium Nasional Inovasi dan Pembelajaran Sains. (SNIPS 2015) (376).

Wahyuni, R. 2019. Pengaruh Model PBL Berbasis STEM untuk Meningkatkan Literasi Sains Peserta Didik. Skripsi Jurusan Fisika- Falkutas Tarbiyah dan Keguruan, 46-47.
Wijayanti, Afilia dan Fajriyah, Khusnul. (2018). Implementasi Stem Project Based Learning untuk Meningkatkan Keteram pilan Kerja Ilmiah Mahasiswa Calon Guru SD. Jurnal Pendidikan Sains, 6(2), 62-69.

Winarni, J., Zubaidah, S dan Koes, S. (2016). STEM: Apa, Mengapa, dan Bagaimana. Pros. Semnas Pend. IPA Pascasarjana UM. 1(976-894). Malang: Universita Negeri Malang. 